\title{
Perancangan Sistem Tata Udara pada Instalasi Ruang Farmasi RSAB Harapan Kita Jakarta
}

\author{
Markus $^{1}$, Iman Firman ${ }^{2}$ \\ ${ }^{1}$ Jurusan Teknik Refrigerasi dan Tata Udara,Politeknik Negeri Bandung,Bandung 40012 \\ E-mail:mks_ra@polban.ac.id \\ ${ }^{2} J u r u s a n$ Teknik Mesin Sekolah Tinggi Teknologi Mandala Bandung,Bandung 40284 \\ E-mail : imanfirman13@gmail.com
}

\begin{abstract}
ABSTRAK
Perancangan sistem tata udara untuk ruang bersih farmasi di Indonesia mengacu pada standar yang diterbitkan oleh Badan Pengawas Obat dan Makanan nomor 34 th. 2018 tentang Pedoman cara Pembuatan Obat yang Baik. Parameter-parameter yang harus memenuhi standar diantaranya adalah temperatur, kelembaban udara relatif, jumlah partikel per $\mathrm{m}^{3}$ udara dan air change per hour. Dalam perancangan ruang zona steril kelas B RSAB Harapan Kita, akan dilakukan perhitungan beban kalor ruangan yang dikondisikan. Standar ruang bersih kelas B adalah: jangkauan temperatur $16{ }^{\circ} \mathrm{C} s / \mathrm{d} 26{ }^{\circ} \mathrm{C}$, kelembaban relatif $45 \%$ s/d $55 \%$, pertukaran udara minimal 20 kali per jam. Untuk kondisi nonoperasional jumlah maksimum partikel per $\mathrm{m}^{3}$ udara yang diperbolehkan untuk ukuran partikel >0,5 $\mu \mathrm{m}$ adalah 3520 partikel dan untuk ukuran partikel $>5 \mu \mathrm{m}$ adalah 29 partikel, sedangkan untuk kondisi operasional jumlah maksimum partikel per $\mathrm{m}^{3}$ udara yang diperbolehkan untuk ukuran partikel $>0,5 \mu \mathrm{m}$ adalah 352000 partikel dan untuk ukuran partikel > $5 \mu \mathrm{m}$ adalah 2900 partikel. Dari hasil perhitungan dengan kondisi standar yang dipersyaratkan, diperoleh besar laju kalor ruang yang harus dikondisikan adalah $18,123 \mathrm{~kW}\left(61,84 \times 10^{3} \mathrm{Btu} / \mathrm{h}\right)$ untuk luas area $58.4 \mathrm{~m}^{2}$, sedangkan untuk mengkondisikan jumlah partikel, dipilih jenis filter High Efficiency Particular Air (HEPA) Filter. Dalam menentukan kapasitas peralatan sistem tata udara, faktor yang menentukan adalah kondisi dan fungsi ruang, kondisi lingkungan, serta persyaratan dari dinas terkait.
\end{abstract}

Kata kunci

Kelembaban udara, perancangan tata udara, clean room, ruang farmasi, zona steril.

\section{PENDAHULUAN}

Sistem tata udara pada industri farmasi mempunyai peranan yang sangat penting, tidak hanya untuk kenyamanan pengguna akan tetapi lebih pada sistem perlindungan dan mutu produk. Sistem tata udara pada industri farmasi sangat erat kaitannya dengan peraturan-peraturan yang berlaku dari dinas terkait. Dalam hal ini Dinas Pengawasan Obat dan Makanan (BPOM) yang banyak mengatur prasyarat kondisi ruang produksi dimana hasilnya adalah mendapatkan mutu produk yang baik.

Cara Pembuatan Obat yang Baik (CPOB) [2] adalah bagian dari pemastian mutu yang memastikan bahwa obat dibuat dan dikendalikan secara konsisten untuk mencapai standar mutu yang sesuai dengan tujuan penggunaan dan dipersyaratkan dalam izin edar dan spesifikasi produk.

Bangunan dan fasilitas untuk pembuatan obat harus memiliki desain, konstruksi dan letak yang memadai, serta disesuaikan kondisinya dan dirawat dengan baik untuk memudahkan pelaksanaan operasi yang benar. Tata letak dan desain ruangan harus dibuat sedemikian rupa untuk memperkecil risiko terjadi kekeliruan, pencemaran silang dan kesalahan lain, serta memudahkan pembersihan, sanitasi dan perawatan yang efektif untuk menghindarkan pencemaran silang, penumpukan debu atau kotoran, dan dampak lain yang dapat menurunkan mutu obat. Dengan kondisi tersebut, perancangan sistem tata udara farmasi harus mampu menterjemahkan prasyarat ruang produksi farmasi dimana sistem dapat mengendalikan temperatur udara serta kelembaban udara. Disamping itu tingkat kebersihan udara serta zonasi tekanan ruang untuk alur produksi, perlu pula dipertimbangakan pencemaran yang bakal ditimbulkan oleh proses produksi dimana sistem extraksi (exhaust) harus dapat mencegah pencemaran baik bagi pengguna maupun lingkungannya.

Tujuan dari perancangan sistem tata udara ruang farmasi adalah menyediakan sistem tata udara sesuai 
dengan CPOB untuk kebutuhan perlindungan produk dan proses sejalan dengan persyaratan GEP (Good Engineering Practice), khususnya dalam menentukan beban pendingin sistem tata udara sesuai dengan kondisi gedung yang dirancang.

\section{TINJAUAN PUSTAKA}

Sistem Tata Udara adalah suatu sistem yang mengkondisikan lingkungan atau ruang melalui pengendalian temperatur, kelembaban nisbi, arah pergerakan udara, kwalitas udara, pengendalian kwantitas partikel, pembuangan kontaminan, termasuk juga kebisingan yang disebabkan oleh mesin tata udara. Sistem tata udara memegang peran penting di industri farmasi, selain menghasilkan produk yang bermutu, diperlukan pula lingkungan kerja yang aman, nyaman dan sehat terhadap partikulat di udara melalui pengaturan sistem penyaringan dan pembuangan. Objek perancangan adalah ruang produksi obat di rumah sakit anak dan bunda harapan kita Jakarta (RSAB).

Berdasarkan uraian di atas, akan dilakukan perancangan ruang bersih (cleanroom) untuk pembuatan obat di RSAB Harapan Kita Jakarta. Ruang bersih atau cleanroom adalah ruang atau area di bawah pengawasan dan pengendalian lingkungan terhadap cemaran partikulat dan mikroba pada tingkat yang telah ditetapkan. Ruang bersih mengontrol temperatur, kelembaban nisbi, pergerakan udara, tekanan udara, kebisingan, dan jumlah partikulat atau mikroba sesuai dengan standar ISO 14644-1[1].Jumlah maksimum partikulat udara yang diperbolehkan untuk tiap kelas kebersihan diatur berdasarkan BPOM No. 13 TAHUN 2018 [2], sebagai berikut:

Tabel 1. Rekomendasi parameter pengkondisian udara untuk ruang bersih tiap kelas kebersihan

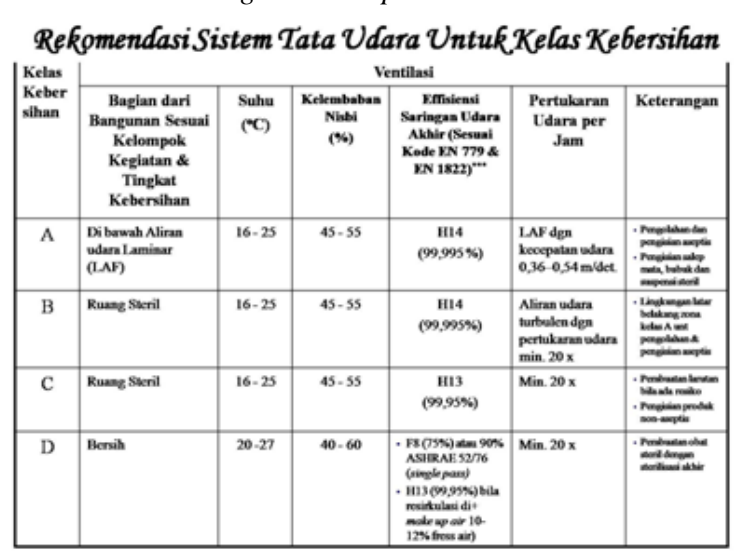

Tabel 2. Jumlah maksimum partikulat udara yang diperbolehkan untuk tiap kelas kebersihan

\begin{tabular}{|c|r|r|r|c|}
\hline \multirow{2}{*}{$\begin{array}{c}\text { Ukuran } \\
\text { Peartikel }\end{array}$} & \multicolumn{2}{|c|}{ Nonoperasional } & \multicolumn{2}{|c|}{ Operasional } \\
\cline { 2 - 5 } & Jumlah maksimum partilkel $/ \mathrm{m}^{3}$ yang diperbolehkan \\
\cline { 2 - 5 } & $\geq 0,5 \mu \mathrm{m}$ & $\geq 5 \mu \mathrm{m}$ & $\geq 0,5 \mu \mathrm{m}$ & $\geq 5 \mu \mathrm{m}$ \\
\hline $\mathrm{A}$ & 3.520 & 20 & 3.520 & 20 \\
\hline $\mathrm{B}$ & 352.000 & 2.900 & 3.520 .000 & 29.000 \\
\hline $\mathrm{D}$ & 3.520 .000 & 29.000 & $\begin{array}{c}\text { Tidak } \\
\text { ditetapkan } \\
\text { Tidak }\end{array}$ & $\begin{array}{c}\text { Tidak } \\
\text { ditetapkan }\end{array}$ \\
\hline E & 3.520 .000 & 29.000 & $\begin{array}{c}\text { Tidak } \\
\text { ditetapkan }\end{array}$ \\
\hline
\end{tabular}

Kelas A, B, C dan D adalah kelas kebersihan ruang untuk pembuatan produk steril, sedangkan kelas $\mathrm{E}$ adalah kelas kebersihan ruang untuk pembuatan produk nonsteril.

Referensi [3]; menyatakan bahwa ruang bersih memiliki tingkat kontaminasi terkontrol yang ditentukan oleh jumlah partikel per meter kubik untuk ukuran partikel tertentu, sesuai dengan aturan yang ditentukan oleh otoritas yang mengatur "Penataan makanan dan obat". Dari hasil penelitian [5] menyimpulkan bahwa: pemanasan, ventilasi, dan tata udara merupakan komponen yang tidak terpisahkan dari fungsi fasilitas farmasi. Dari [6] diperoleh: beban pendinginan untuk 4 ruang dengan sistem tata udara yang sudah terpasang di lapangan adalah 397.700 Btu/h, sedangkan dari perhitungan ulang didapat beban pendingin yang dibutuhkan 204.404 Btu/h sehingga terjadi penurunan sebesar 49\%. Dari [7] untuk ruang bersih farmasi kelas E, didapat beban pendinginan desain sebesar 17329.077 Watt dengan kecepatan distribusi udara di jalan nafas sebesar $0,118 \mathrm{~m} / \mathrm{s}$ dengan kebutuhan udara $99.6151 / \mathrm{s}$, sehingga memenuhi persyaratan untuk kelas E (100.000) menurut ISO 14644-1, dan temperatur ruangan diperoleh $21{ }^{\circ} \mathrm{C}$ dengan kelembaban 40\%. Referensi [8] melakukan perhitungan beban pendingin pada Gedung Aula SMK Negeri 1 Sekayu menggunakan metode perhitungan CLTD ( Cooling Load Temperature Difference ) berdasarkan ASHRAE GRP 158 Cooling Load Calculation Manual, didapat hasil beban pendingin maksimum sebesar 23.7013,1917 Btu/hr untuk aula dengan dimensi $18 \mathrm{~m}$ x $16 \mathrm{~m}$ x 6 m. Referensi [9] melakukan perancangan sistem tata udara untuk mengurangi Hospital-acquired Infections (HAIs, atau yang biasa disebut dengan infeksi nosokomial) pada ruang NICU. Metode perhitungan kapasitas pendinginan yang digunakan adalah dengan menggunakan Cooling Load Temperature Difference (CLTD), sedangkan metode yang digunakan dalam merancang saluran distribusi udara adalah metode Equal Friction Loss. Dari hasil perhitungan, didapat kapasitas pendinginan untuk ruang NICU adalah sebesar $8,803 \mathrm{~kW}$ dan kapasitas 
pemanasannya adalah sebesar $3,660 \mathrm{~kW}$. Referensi [10] melakukan desain saluran udara untuk kereta ukur sulawesi dengan kapasitas pendinginan minimum $31,1 \mathrm{~kW}$, saluran udara dirancang dengan dua bentuk, lurus dan bercabang. Analisis menggunakan software berbasis CFD, didapat saluran udara bercabang dengan variasi sudut 75 derajat, suhu rata-rata $77,51^{\circ} \mathrm{F}$, kelembaban relatif $78,3 \%$, dan kecepatan uadra rata-rata 66,81 fpm. Referensi [11] melakukan penelitian: membandingkan data yang diambil dari sebuah perusahaan pembuatan obat dengan hasil studi literatur sesuai yang standar CPOB yang berlaku. Hasil penelitian menunjukkan bahwa faktor kritisnya adalah udara yang diukur pada suhu 17-22 ${ }^{0} \mathrm{C}$ dengan $\mathrm{RH} 45-57 \%$ dan memenuhi standar CPOB yaitu suhu $16-25{ }^{\circ} \mathrm{C}$ dengan $\mathrm{RH} 45-55 \%$. Debit pasokan udara pengenal adalah $5.000 \mathrm{~m}^{3} / \mathrm{jam}$ dengan pertukaran udara / ACH (Air Change Hour), memenuhi standar rata-rata 118,5 kali per jam. Sedangkan debit balik yang diukur adalah 750-2000 $\mathrm{m} 3$ / jam dan disirkulasi ulang dengan baik. Jumlah partikel untuk ukuran $0,5 \mu \mathrm{m}$ dan $5 \mu \mathrm{m}$ adalah 38.081, dan 46 partikel memenuhi standar CPOB karena maksimum standar adalah 325.000 dan 2.900 partikel.

\section{METODOLOGI PENELITIAN}

Penelitian diawali dengan studi pustaka pada jurnal dan artikel tentang perancangan sistem tata udara ruang, khususnya ruang produksi farmasi. Dari hasil studi sebelumnya diperoleh sejumlah informasi yang dapat dijadikan landasan dalam menentukan referensi yang dapat mendukung dan sebagai pembanding untuk perancangan. Referensi dituangkan dalam bentuk tinjauan pustaka, kemudian dapat ditentukan langkah perancangannya. Menghitung beban pendingin ruang produksi, menentukan dimensi dacting (saluran udara) dan volume ducting, selanjutnya menentukan kapasitas peralatan yang harus digunakan. Selain menghasilkan dara rancangan, penelitian ini juga menghasilkan karya ilmiah yang akan disubmit ke prosiding atau diterbitkan dalam bentuk jurnal nasional (JURNAL TEKNIK ENERGI POLBAN).

\section{HASIL DAN PEMBAHASAN}

\section{DATA FISIK BANGUNAN}

Ruang farmasi yang dirancang terletak di lingkungan Rumah Sakit Anak Bersalin (RSAB) Harapan Kita Jakarta. Ruang farmasi merupakan ruang steril class B. Data rancangan diambil dengan mengukur luas tiap ruangan, menghitung beban pendingin tiap ruangan, dan temperature ambient. Sedangkan data temperature, air change hour $(\mathrm{ACH})$, relative humidity $(\mathrm{RH})$, dan tekanan tiap ruangan mengikuti persyaratan dari BPOM dan standar CPOB (CPOB 2018). Data ruang steril ditunjukkan pada table berikut:

Tabel 3. Kondisi kebutuhan ruang zone steril

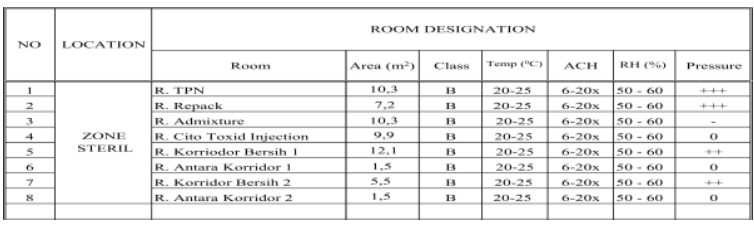

\section{HASIL DAN PEMBAHASAN}

Untuk menentukan kapasitas unit Air Conditioning (AC), dapat dihitung dari perkiraan-perkiraan kondisi fisik bangunan, peralatan, utilitas dan aktifitas yang terdapat dalam gedung. Beban pendingin dapat dikelompokkan menjadi dua bagian, yaitu beban external dan beban internal. Beban external lebih banyak dipengaruhi oleh kondisi lingkungan luar, terutama terhadap efek sinar matahari yang mengenai konstruksi bangunan baik secara langsung maupun tidak langsung, demikian pula beban pendingin akibat infiltrasi dan ventilasi udara luar yang masuk ke ruangan. Beban internal mencakup jumlah dan aktivitas orang didalam ruangan, lampu, peralatan, motor-motor listrik, dan sumber-sumber lain yang menimbulkan panas didalam ruangan.

\section{Perhitungan beban pendingin total zona steril}

Dari data Zone Steril, ada 8 (delapan) ruang yang dikatagorikan zone steril dengan kelas B. Untuk contoh perhitungan, diambil sampel ruang TPN.

\section{Data outdoor :}

Temperatur dry bulb : $35^{\circ} \mathrm{C}\left(95^{\circ} \mathrm{F}\right)$

Temperatur wet bulb : $27.6^{\circ} \mathrm{C}\left(81.6^{\circ} \mathrm{F}\right)$

RH : $70 \%$

Moisture of content : 179 gr/lb of dry air

Data indoor :

Temperatur dry bulb : $22^{\circ} \mathrm{C}\left(72^{\circ} \mathrm{F}\right)$

Temperatur wet bulb : $16.3^{\circ} \mathrm{C}\left(61.4^{\circ} \mathrm{F}\right)$

RH : $: 55 \%$

Moisture of content : $64.4 \mathrm{gr} / \mathrm{lb}$ of dry air Untuk parameter-parameter yang menjadi bahan perhitungan lainnya diasumsikan sebagai berikut :

Tabel 4. Parameter ruang yang dikondisikan 


\begin{tabular}{|l|l|l|ll|}
\hline Parameter & Satuan (IP) & Satuan (SI) & Keterangan \\
\hline Kebutuhan udara segar & $10 \mathrm{cfm} /$ orang & $\begin{array}{l}4.719 \quad \text { LPS } \\
\text { Orang }\end{array}$ & $\begin{array}{l}\text { Tabel 45 Camier } \\
\text { Handbook }\end{array}$ \\
\hline Beban Pencahayaan & $\begin{array}{l}\text { Total Watt lampu x } \\
3.4\end{array}$ & & $\begin{array}{l}\text { Tabel 49 Carrier } \\
\text { Handbook }\end{array}$ \\
\hline Beban Sensible Orang & 306.82 Btuh/ orang & 90 Watt / Orang & $\begin{array}{l}\text { Tabel 48 Camier } \\
\text { Handbook }\end{array}$ \\
\hline Beban Laten Orang & 323.86 Btuh/ orang & 95 Watt / Orang & $\begin{array}{l}\text { Tabel 48 Carrier } \\
\text { Handbook }\end{array}$ \\
\hline Tingkat Hunian & $80 \mathrm{ft}^{2} /$ orang & $7.4 \mathrm{~m}^{2} /$ Orang & Berdasarkan asumsi \\
\hline & & & akupansi ruangan \\
\hline
\end{tabular}

\section{Beban Kalor Sensibel}

Beban sensibel adalah beban panas ruangan yang timbul akibat dari perbedaan temperature (tanpa perubahan fasa/penguapan). Beban sensibel dibagi 2 (dua) yaitu beban external dan beban internal. Beban sensibel external disebabkan oleh rambatan panas dari luar ruangan yang dikondisikan melaui konstruksi gedung (melalui dinding, kacap, partisi, ceiling dan atap). Sedangkan beban sensibel internal disebabkan oleh peralatan dan aktifitas orang didalam ruangan (orang, peralatan, lampu, steam dil). Ventilasi dan infiltrasi udara ke dalam ruangan terdiri dari beban sensibel dan beban laten, karena udara luar selain temperature itu sendi juga mengandung uap air. Infiltarsi terkadang diabaikan karena ruangan dianggap kedap dari kebocoran. Ruang TPN mempunyai konstruksi dinding sebelah barat berhubungan dengan luar ruangan, sementara bagian timur dan selatan berbatasan dengan ruangan yang dikondisikan, sedangkan dinding utara bersebelahan dengan ruangan lain yang tidak dikondisikan.

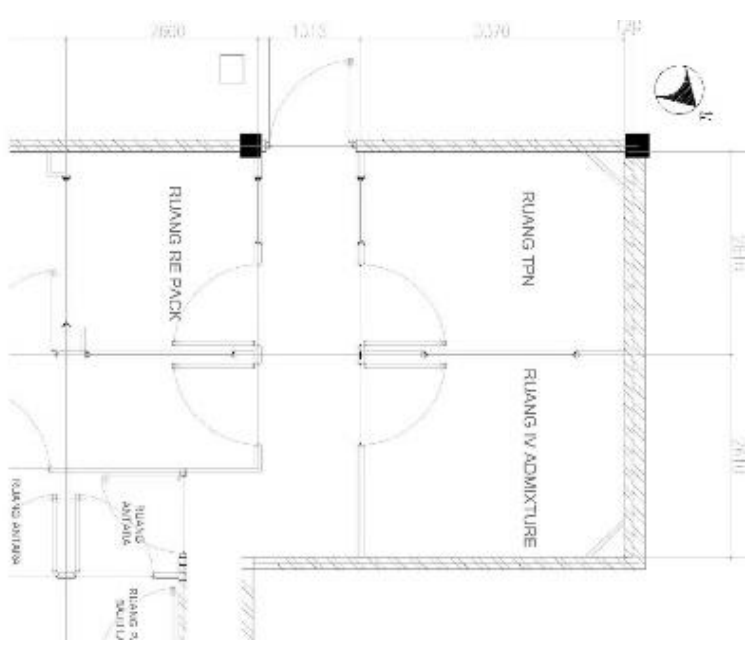

Gambar 1. Deskripsi ruang TPN

\section{Beban Kalor Sensibel External}

Beban sensibel melalui dinding dapat dihitung melalui persamaan :

\author{
$Q=U \times A \times \Delta T$ \\ $Q=$ Beban pendinginan $(\mathrm{Btu} / \mathrm{hr})$ \\ $A=$ Luas dinding $\left(\mathrm{ft}^{2}\right)$ \\ $U=$ Koefisien total rambatan thermal \\ (Btu/hr.ft $\left.{ }^{2} . \mathrm{F}\right)$ \\ $\Delta T=$ Perbedaan Temperatur $\left({ }^{\circ} \mathrm{F}\right)$
}

Koefisien rambatan thermal " $U$ " merupakan total penjumlahan rambatan thermal akibat adanya perbedaan temperatur $1^{\circ} \mathrm{K}$ pada satu bidang ke bidang lainnya. Nilai " $U$ " sangat dipengaruhi oleh ketebalan dan material yang digunakan. Semakin tebal dinding dan semakin isolator sifat bahan maka nilai $U$ akan semakin kecil. Untuk mendapatkan nilau $U$ dapat dihitung dengan persamaan berikut:

$$
\frac{1}{U}=\frac{1}{f o}+\frac{x 1}{k 1}+\frac{x 2}{k 2}+\frac{x 3}{k 3}+\frac{x n}{k n}+\frac{1}{f i}
$$

$U=$ Koefisien total perambatan panas suatu bahan $\left(\mathrm{Btu} / \mathrm{hr} . \mathrm{ft}^{2} . \mathrm{F}\right) /\left(\mathrm{W} / \mathrm{m}^{2} \mathrm{~K}\right)$

$k=$ konduktifitas termal dinding (Btu /hr.ft.F)/

(W/m.K)

$x=$ tebal dinding $(\mathrm{ft}) /(\mathrm{m})$

$f o, f i=$ koefisien konveksi udara diam dan bergerak (Btu/hr.ft $\left.{ }^{2} . \mathrm{F}\right) /\left(\mathrm{W} / \mathrm{m}^{2} \mathrm{~K}\right)$

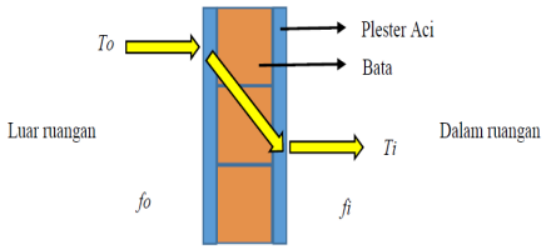

Gambar 2. Konstruksi dinding ruang TPN

Tabel 5. Koefisien konduktivitas termal dinding

\begin{tabular}{|c|c|c|c|}
\hline \multirow[t]{2}{*}{ Material } & \multirow{2}{*}{$\begin{array}{c}\text { Tebal } \\
(\mathrm{m})\end{array}$} & $\begin{array}{c}\text { Kond } \\
\text { thermal }\end{array}$ & Konduktansi \\
\hline & & $\boldsymbol{k}(\mathrm{W} / \mathrm{m} . \mathrm{K})$ & $C\left(\mathrm{~W} / \mathrm{m}^{2} \mathrm{~K}\right)$ \\
\hline Koef. konveksi udara diam & & & 0.106724 \\
\hline Aci & 0.0002 & 0.029 & 0.006897 \\
\hline Plester & 0.002 & 0.33 & 0.006061 \\
\hline Bata Merah & 0.015 & 0.72 & 0.020833 \\
\hline Plester & 0.002 & 0.33 & 0.006061 \\
\hline Aci & 0.0002 & 0.029 & 0.006897 \\
\hline Koef. konveksi udara bergerak & & & 0.044053 \\
\hline Total Konduktansi & & & 0.197524 \\
\hline Total $\mathrm{U}\left(\mathrm{W} / \mathrm{m}^{2} \mathrm{~K}\right) \mathrm{l} / \mathrm{C}$ & & & 5.062673 \\
\hline Total U (Btu/hr.ft $\left.{ }^{2} . \mathrm{F}\right)$ & & & 0.891630 \\
\hline $\begin{array}{l}\left.\text { Total U (Btu/hr.ft }{ }^{2} . \mathrm{F}\right) \\
\text { Pembulatan }\end{array}$ & & & 0.900000 \\
\hline
\end{tabular}

Luas dinding yang menghadap kearah barat, $\mathrm{A}=$ $7.8 \mathrm{~m}^{2}\left(84 \mathrm{ft}^{2}\right)$ 
Perbedaan temperatur diambil dari perbedaan temperatur luar ruangan dengan temperatrur dalam ruangan, $\Delta T=95^{\circ} \mathrm{F}-72^{\circ} \mathrm{F}=23^{\circ} \mathrm{F}$.

Maka beban pendingin melalui dinding raung TPN adalah:

$$
\begin{gathered}
Q=U x A x \Delta T \\
\boldsymbol{Q d}=\mathbf{0 . 9} \times \mathbf{8 4} \times \mathbf{2 3}=\mathbf{1 7 3 8} \mathrm{Btu} / \mathrm{hr}
\end{gathered}
$$

\section{Beban melalui partisi}

Beban partisi merupakan beban perpindahan panas antara ruang yang tidak bersinggungan langsung dengan lingkungan luar (outdoor). Beban partisi merupakan beban konstruksi antar ruang. Ada 2 jenis partisi yang digunakan dalam bangunan, yaitu partisi dinding bata dan partisi sandwich panel yaitu lembaran plat allumunium yang diberi insulasi. Tujuannya selain untuk kebersihan juga memiliki hambatan thermal yang baik (nilai $U$ yang rendah). Untuk menyederhanakan perhitungan, diasumsikan maksimal suhu ruangan yang dikondisikan adalah $25^{\circ} \mathrm{C}\left(77^{\circ} \mathrm{F}\right)$. Sementara untuk ruangan yang dikondisikan dan menggunakan sandwich panel, diasumsikan temperatur kedua sama, sehingga tidak ada beban pendinginan. Untuk menghindari adanya kebocoran panas pada dinding partisi, diasumsikan ada selisih temperature sebesar $5^{\circ} \mathrm{C}\left(10^{\circ} \mathrm{F}\right)$, hal ini diasumsikan saat salah satu AC dalam kondisi off.

Tabel 6. Koefisien konduktivitas termal dinding partisi

Partisi Dinding
\begin{tabular}{|l|r|c|r|}
\hline \multicolumn{1}{|c|}{ Material } & \multirow{2}{*}{$\begin{array}{c}\text { Tebal } \\
\end{array}$} & $\begin{array}{c}\text { Kond } \\
\text { thermal }\end{array}$ & Konduktansi \\
\cline { 3 - 4 } & & $\boldsymbol{k}(\mathrm{W} / \mathrm{m} . \mathrm{K})$ & $\boldsymbol{C}\left(\mathrm{W} / \mathrm{m}^{2} \mathrm{~K}\right)$ \\
\hline Koef. konveksi udara diam & & & 0.106724 \\
\hline Semen & 0.0002 & 0.029 & 0.006897 \\
\hline Plester & 0.002 & 0.33 & 0.006061 \\
\hline Bata Merah & 0.015 & 0.7 & 0.021429 \\
\hline Semen & 0.002 & 0.33 & 0.006061 \\
\hline Aci & 0.0001 & 0.029 & 0.003448 \\
\hline Koef. konveksi udara diam & & & 0.106724 \\
\hline Total Konduktansi & & & 0.257342 \\
\hline Total U (W/m ${ }^{2}$ K) $1 / \mathrm{C}$ & & & 3.885883 \\
\hline Total U (Btu/hr.ft ${ }^{2}$.F) & & & 0.684375 \\
\hline Total U (Btu/hr.ft ${ }^{2}$.F) Pembulatan & & & 0.700000 \\
\hline
\end{tabular}

Untuk luas dinding partisi yang menghadap utara A $=8.2 \mathrm{~m}^{2}\left(88.8 \mathrm{ft}^{2}\right)$. Untuk Perbedaan temperatur diambil dari perbedaan temperature luar ruangan dengan dalam ruangan $\Delta T=77^{\circ} \mathrm{F}-63^{\circ} \mathrm{F}=14^{\circ} \mathrm{F}$. Maka beban pendingin melalui dinding raung TPN :

$$
\begin{gathered}
Q=U \times A \times \Delta T \\
\text { Qpd }=\mathbf{0 . 7} \times \mathbf{8 8 . 8} \times \mathbf{1 4}=\mathbf{8 7 0} \mathrm{Btu} / \mathrm{hr}
\end{gathered}
$$

\section{Beban pendinginan melalui sandwich panel}

Luas partisi sandwich panel yang menghadap ke timur dan selatan: $A=19.5 \mathrm{~m}^{2}\left(209.9 \mathrm{ft}^{2}\right)$. Untuk perbedaan temperatur diambil dari perbedaan temperature luar ruangan dengan dalam ruangan $\Delta T$ $=10{ }^{\circ} \mathrm{F}$. Maka beban pendinginan melalui sandwich panel raung TPN adalah:

$$
Q=U \times A x \Delta T
$$

$$
Q s p=0.1 \times 209.9 \times 10=210 \mathrm{Btu} / \mathrm{hr}
$$

Beban pendinginan melalui ceiling sandwich panel

Untuk luas ceiling sandwich panel yang menghadap timur dan selatan $A=10.3 \mathrm{~m}^{2}\left(111 \mathrm{ft}^{2}\right)$. Untuk Perbedaan temperatur diambil dari perbedaan temperature luar ruangan dengan dalam ruangan $\Delta T$ $=77^{\circ} \mathrm{F}-63^{\circ} \mathrm{F}=14^{\circ} \mathrm{F}$. Maka beban pendingin melalui dinding ceiling sandwich panel untuk raung TPN adalah:

$$
\begin{gathered}
Q=U \times A \times \Delta T \\
Q c=\mathbf{0 . 1} \times \mathbf{1 1 1} \times \mathbf{1 4}=\mathbf{1 5 5 \mathrm { Btu } / \mathrm { hr }}
\end{gathered}
$$

\section{Beban Sensibel Internal} Beban sensibel orang

Beban sensibel orng dihitung berdasarkan jumlah orang dikali dengan kalor sensibel. Kalor sensibel orang bergatung dari aktifitasnya. Pada tabel 2.4, diasumsikan orang beraktifitas ringan dengan kalor sensibel qs $=306.82 \mathrm{Btu} / \mathrm{hr}$.orang. Menentukan jumlah orang dalam suatu ruangan bisa diprediksi dari akupansi (kepadatan) orang per satuan luas. Dalam perhitungan ini ditentukan akupansi sekitar $80 \mathrm{ft}^{2} /$ orang. Dengan luasan ruang TPN $=10.3 \mathrm{~m}^{3}$ $\left(111 \mathrm{ft}^{3}\right)$ perkiraan rata-rata orang :

$N=\frac{111}{80}$

$N=1.38$ org, dibulatkan menjadi 2 org

Beban sensibel orang:

$$
Q s o=2 \times 306,82=613,6 \mathrm{Btu} / \mathrm{h}
$$

\section{Beban sensibel lampu}

Selain menghasilkan cahaya, lampu juga mengeluarkan panas. Menentukan jumlah panas yang dilepaskan oleh lampu bisa diprediksi dengan jumlah daya listrik lampu yang digunakan per satuan luas. Dari tabel didapat beban panas sebesar $3 \mathrm{Watt} / \mathrm{ft}^{2}$

Maka $3 \mathrm{Watt} / \mathrm{ft}^{2}$ x $111 \mathrm{ft}^{2}=333$ Watt $(1137 \mathrm{Btu} / \mathrm{hr})$ 
Jadi Qlamp = 1137 Btu $/ \mathrm{hr}$

\section{Beban kalor Sensibel total:}

$$
\begin{gathered}
Q s=Q d+Q p d+Q s p+Q c+Q s o+\text { Qlamp } \\
Q s=1738+870+210+155+613,6+1137 \\
Q \boldsymbol{Q s}=\mathbf{4 7 2 4} \text { Btu } / \boldsymbol{h r}
\end{gathered}
$$

Untuk mengantisifasi kesalahan dalam perancangan dan faktor lainnya, maka perlu ditambahkan faktor keamanan (safety factor) sebesar $2.5 \%$, yaitu $2.5 \% \times 4724=118 \mathrm{Btu} / \mathrm{hr}$, sehingga beban sensibel total adalah Qst $=\mathbf{4 7 2 4}+118=$ $4842 \mathrm{Btu} / \boldsymbol{h r}$. Beban sensibel total disebut juga sebagai room sensible heat load (RSHL)

\section{Rugi kalor sepanjang saluran ducting}

Walaupun dinding luar ducting diinsulasi, namun gesekan udara dengan dinding sebelah luar ducting dapat menimbulkan kenaikan temperatur, selain itu kebocoran udara pada ducting masih mungkin terjadi. Untuk mengantisifasi kerugian kalor tersebut, maka perlu diberikan faktor keamanan (supply duct heat gain loss) sebesar $5 \%$ dari room sensible heat load. Sehingga didapat room sensible heat ducting sebesar:

$$
\text { Qrshd }=5 \% x 4842=242 \text { Btu } / \text { hr } .
$$

\section{Beban kalor ventilasi}

Ventilasi ditujukan untuk memasok udara segar ke ruangan karena adanya aktifitas di dalam ruangan. Dalam perhitungan, diasumsikan kebutuhan udara ventilasi setiap orangnya sebesar $10 \mathrm{cfm} / \mathrm{orang}$.

Beban sensibel ventilasi dapat dihitung dengan persamaan :

$$
Q v s=1.08 \times c f m \times \Delta T
$$

$c f m .=$

Jumlah volume udara ventilasi ( $\mathrm{ft}^{3} /$ menit)

$c f m=2$ orang $x 10 c f m=20 c f m\left(\mathrm{ft}^{3} /\right.$ menit $)$

Dalam perhitungannya perlu dimasukkan Bypass Factor karena udara ventilasi tidak melewati peralatan tata udara (Coil pendingin). Ditentukan bypass factor sebesar 0.1, maka persamaannya menjadi :

$$
\begin{gathered}
Q v s=1.08 \times c f m \times B F \times \Delta T \\
Q v \boldsymbol{v}=\mathbf{1 . 0 8} \boldsymbol{x} \mathbf{2 0} \boldsymbol{x} \mathbf{0 . 1} \boldsymbol{x} 23=\mathbf{5 0} \mathbf{B t u} / \mathbf{h r}
\end{gathered}
$$

Effective room sensibel heat (ERSH) merupakan total beban sensibel ruangan dengan menambahkan faktor beban heat duct gain loss dan beban ventilasi sensibel orang:

$$
\begin{gathered}
E R S H=R S H L+Q r s h d+Q v s \\
\boldsymbol{E R S H}=\mathbf{4 8 4 2}+\mathbf{2 4 2}+\mathbf{5 0}=\mathbf{5 1 3 4} \mathbf{B t u} / \boldsymbol{h r}
\end{gathered}
$$

\section{Beban Kalor Laten \\ Beban Kalor Laten Internal}

Beban laten internal salah satunya adalah beban laten orang. Aktifitas orang selain mengahasilkan kalor sensibel juga menghsilkan kalor laten. Untuk aktifitas ringan kalor laten orang ditentukan sebesar 323.86 Btu/hr/orang

$$
Q l o=n \times q l=2 \times 323.86=648 \mathrm{Btu} / \mathrm{hr}
$$

Dengan memasukkan safety factor sebesar $2.5 \%$, didapat: $Q=2.5 \% \times 648=16 \mathrm{Btu} / \mathrm{hr}$.

Total beban laten adalah Qlt $=\mathbf{6 4 8}+\mathbf{1 6}=$ $664 \mathrm{Btu} / \mathrm{hr}$

Beban kalor laten total disebut juga sebagai room laten heat load (RLHL). Dengan menambahkan duct laten heat gain loss sebesar $5 \%$, maka didapat:

$$
\text { Qrlhd }=5 \% \times 664=33 \mathrm{Btu} / \mathrm{hr}
$$

Dengan memasukkan nilai bypass Factor yaitu faktor udara yang tidak melewati peralatan tata udara (Coil pendingin) sebesar 0.1, maka persamaannya menjadi:

$$
\begin{gathered}
\text { Qls =0.68 } \times \text { cfm } \times B F \times \Delta W \\
\Delta W=\text { Moisture of content } W \text { outdor } \\
- \text { Windoor }\left(\frac{g r}{g r d a}\right) \\
\text { Qls }=\mathbf{0 . 6 8} \times \mathbf{2 0} \times \mathbf{0 . 1} \times(\mathbf{1 7 9}-\mathbf{6 4 . 4}) \\
=156 \mathrm{Btu} / \mathrm{hr}
\end{gathered}
$$

Effective room laten heat (ERLH) merupakan total beban laten ruangan dengan menambahkan faktor beban heat duct gain loss dan beban ventilasi laten orang:

$$
\begin{aligned}
& E R L H=R L H+Q r l h d+Q l s \\
& \text { ERLH }=\mathbf{6 4 8}+\mathbf{3 3}+\mathbf{1 5 6}=\mathbf{8 5 3} \text { Btu } / \mathbf{h r}
\end{aligned}
$$

\section{Beban Kalor Laten External}

Udara ventilasi yang masuk ke ruangan melalui coil pendingin merupakan beban sensibel dan laten, dan besarnya adalah (1- Bypass Factor), maka beban ventilasi outdoor dihitung dengan persamaan:

$$
\begin{aligned}
& \text { Qvens }=1.08 \times c f m \times(1-B F) \times \Delta T \\
& \text { Qvenl }=0.68 \times c f m \times(1-B F) \times \Delta W
\end{aligned}
$$




$$
\begin{gathered}
\text { Qvens }=1.08 \times 20 x(1-0.1) \times 23 \\
=447 \mathrm{Btu} / \mathrm{hr} \\
\text { Qvenl }=0.68 \times 20 x(1-0.1) \times 114.6 \\
=1403 \mathrm{Btu} / \mathrm{hr}
\end{gathered}
$$

Sehingga didapat:

Beban sensibel total: Qts $=E R S H+$ Qvens $=$ $5134+447=5581 \mathrm{Btu} / \mathrm{hr}$

Beban laten total: $Q t l=E R L H+Q v e n l=853+$ $1403=2256$ Btu $/$ hr

Grand total beban pendinginan untuk ruang TPN adalah:

$$
\begin{array}{r}
Q t o t=Q t s+Q t l=5581+2257 \\
=7836 \mathrm{Btu} / \mathrm{hr}
\end{array}
$$

\section{Analisis Diagram Psychrometric}

Diagram psychrometric membantu dalam perhitungan, analisis kerja, perpindahan energi dari proses, dan siklus sistem tata udara. Dari analisis tersebut dapat diketahui laju aliran udara dan proses pendinginan udara, terutama untuk mengamati kandungan uap air dalam udara pada setiap proses pengkondisian udara.

Berikut data-data yang digunakan untuk analisis menggunakan diagram psikometri:

Data udara outdoor :

Temperatur dry bulb : $35^{\circ} \mathrm{C}\left(95^{\circ} \mathrm{F}\right)$

Temperatur wet bulb : $27.6^{\circ} \mathrm{C}\left(81.6^{\circ} \mathrm{F}\right)$

RH : $70 \%$

Moisture of content $(W): 179 \mathrm{gr} / \mathrm{lb}$ of dry air

Data udara indoor :

Temperatur dry bulb : $22^{\circ} \mathrm{C}\left(72^{\circ} \mathrm{F}\right)$

Temperatur wet bulb: $16.3^{\circ} \mathrm{C}\left(61.4^{\circ} \mathrm{F}\right)$

RH : $55 \%$

Moisture of content (W): $64.4 \mathrm{gr} / \mathrm{lb}$ of dry air

$$
\begin{aligned}
& R S H L=4842 \mathrm{Btu} / \mathrm{hr} \\
& R L H L=664 \mathrm{Btu} / \mathrm{hr} \\
& E R S H=5134 \mathrm{Btu} / \mathrm{hr} \\
& E R L H=853 \mathrm{Btu} / \mathrm{hr}
\end{aligned}
$$

Langkah pertama adalah menentukan ESHF (Effectif Sensible Heat Factor):

$$
\begin{gathered}
E S H F=\frac{E R S H}{E R S H+E R L H} \\
E S H F=\frac{5134}{5134+853}=0.86
\end{gathered}
$$

Pada diagram psikometrik, tarik garis ESHF ke titik aligment center $\left(80^{\circ} \mathrm{F}, 50 \% \mathrm{RH}\right)$. Kemudian tarik garis sejajar dengan garis ESHF ke titik ruangan yang di kondisikan. Garis tersebut adalah garis RSHF yang merupakan garis proses pendinginan dari coil pendingin ke ruangan. Dari garis RSHF ini dapat ditentukan temperatur dew point/tadp (temperatur pengembunan). Temperatur dew point adalah temperatur udara supply ketika melalui coil pendingin dan tepat terjadi pengembunan. Nilai tadp dapat dilihat dari tadp dapat dilihat dari tabel ( tabel 65 Carrier Air Conditioning Handbook), atau dapat dilihat dari karekteristik unit ac yang dipilih.
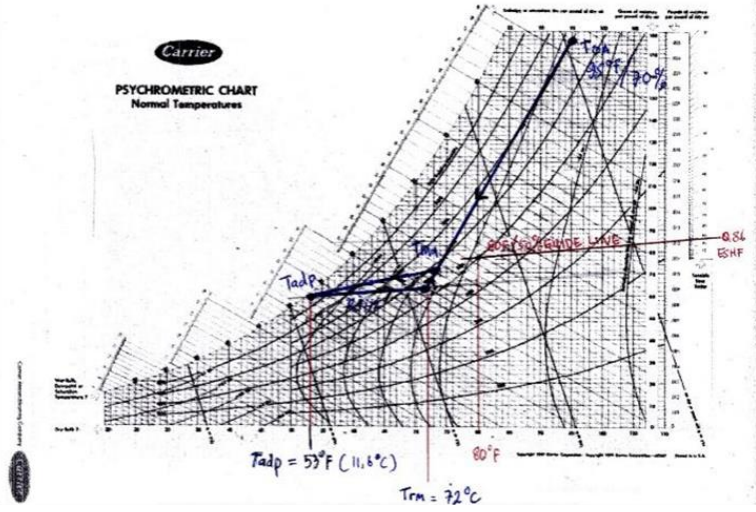

Gambar 3. Garis ESHF dan RSHF pada proses pengkondisian udara ruang TPN

Dari tabel 65 dengan RSHF $=0.86, \operatorname{Trm}=72^{\circ} \mathrm{F}$ dan $\mathrm{Rh}=55 \%$, didapat tadp $=53^{\circ} \mathrm{F}$. Untuk menentukan udara supply digunakan persamaan :

$$
\begin{gathered}
c f m s a=\frac{E R S H}{1.08 \times(1-B F) \times(t r m-t a d p)} \\
c f m s a=\frac{5.134}{1.08 \times(1-0.1) \times(72-53)} \\
c \boldsymbol{f m s a}=\mathbf{2 7 8} \boldsymbol{c f m}
\end{gathered}
$$

Jumlah udara ventilasi telah ditentukan sesuai jumlah orang yaitu $c f m o a=20 c f$,Sehingga jumlah udara return (udara balikan) adalah :

$$
\begin{gathered}
c f m r a=c f m s a-c f m o a \\
c f m r a=278-20=258 c f m
\end{gathered}
$$

Dengan adanya pencampuran udara balik dan udara luar, maka akan terjadi perubahan temperatur ketika saat akan masuk ke koil pendingin. Temperatur udara campuran (mixing air) dapat dihitung dengan persamaan :

$$
t m a=\frac{(c f m o a \times t o a)+(c f m r a \times t r m)}{c f m s a}
$$




$$
t m a=\frac{(20 \times 95)+(258 \times 72)}{278}
$$

$$
\text { tma }=73.7^{\circ} \mathrm{F}\left(23^{\circ} \mathrm{C}\right)
$$

Temperatur udara masuk ke koil pendingin ( entering temperature to apparatus ), relative akan sama dengan temperature pencampuran udara (mixin air). Perhitungan diatas merupakan temperature dry bulb, untuk menghitung temperatur wet-bulb nya digunakan persamaan :

$$
\begin{gathered}
\text { tmawb }=\frac{(\text { cfmoa } x \text { twboa })+(\text { cfmra } x \text { trmwb })}{c f m s a} \\
\text { tmawb }=\frac{(20 \times 81.6)+(258 \times 61.4)}{278} \\
\text { tmawb }=62.9^{\circ} \mathrm{F} \boldsymbol{w b}\left(\mathbf{1 7}^{\circ} \mathrm{C}\right)
\end{gathered}
$$

Udara campuran (mixing air) kemudian diproses menjadi udara dingin oleh coil pendingin. Temperatur keluar dari coil pendingin merupakan temperatur udara dingin yang akan disupply ke ruangan. Untuk perkiraannya dapat dihitung dengan persamaan :

$$
\begin{gathered}
t s a=t a d p+(B F \times(t m a-t a d p) \\
t s a=53+(0.1 \times(73.3-53)) \\
\text { ts } \boldsymbol{a}=\mathbf{5 5}^{\circ} \mathrm{F}\left(\mathbf{1 2 . 8}^{\circ} \mathrm{C}\right)
\end{gathered}
$$

\begin{tabular}{|c|c|c|c|c|c|c|c|}
\hline \multirow{2}{*}{$\begin{array}{l}\mathrm{N} \\
\mathrm{o}\end{array}$} & \multirow{2}{*}{ Ruang } & \multirow{2}{*}{$\begin{array}{l}\text { Fres } \\
\text { h air } \\
\\
\text { Cap } \\
\text { acity } \\
(\boldsymbol{C F} \\
\text { M) }\end{array}$} & \multirow{2}{*}{$\begin{array}{l}\text { Supp } \\
\text { ly air } \\
\\
\text { Capa } \\
\text { city } \\
\text { (CF } \\
\text { M) } \\
\end{array}$} & \multirow{2}{*}{$\mathrm{ACH}$} & \multicolumn{3}{|c|}{ Cooling capacity (Watt) } \\
\hline & & & & & $\begin{array}{c}\text { Sensib } \\
\text { el }\end{array}$ & Latent & Total \\
\hline 1 & TPN & 20 & 278 & 15.27 & 1635.2 & 661.0 & 2296.2 \\
\hline 2 & Repack & 10 & 188 & 14.89 & 1082.6 & 330.5 & 1413.1 \\
\hline 3 & Admixture & 100 & 376 & 20.63 & 2032.5 & 2487.6 & 4520.1 \\
\hline 4 & $\begin{array}{l}\text { Cito Toxid } \\
\text { Injection }\end{array}$ & 100 & 444 & 25.42 & 2404.9 & 2487.6 & 4892.5 \\
\hline 5 & $\begin{array}{l}\text { Koridor } \\
\text { bersih } 1\end{array}$ & 20 & 285 & 13.31 & 1672.7 & 661.0 & 2333.7 \\
\hline 6 & $\begin{array}{l}\text { Antara } \\
\text { koridor } 1\end{array}$ & 20 & 65 & 24.13 & 351.3 & 558.8 & 910.1 \\
\hline 7 & $\begin{array}{l}\text { Koridor } \\
\text { bersih } 2\end{array}$ & 10 & 84 & 8.62 & 520.1 & 330.5 & 850.6 \\
\hline 8 & $\begin{array}{l}\text { Antara } \\
\text { koridor } 2\end{array}$ & 20 & 65 & 24.04 & 350.1 & 558.8 & 908.9 \\
\hline
\end{tabular}

Untuk menghitung temperatur wet-bulb nya digunakan persamaan :

$$
\begin{gathered}
\text { tsawb }=\text { tadp }+(B F x(\text { tmawb }- \text { tadp }) \\
\text { tsawb }=53+(0.1 \times(62.8-53) \\
\text { tsawb }=\mathbf{5 4}^{\circ} \mathrm{F}\left(\mathbf{1 2 . 2}^{\circ} \mathrm{C}\right)
\end{gathered}
$$

Tabel 7. Tabel perhitungan zone steril.

\begin{tabular}{|c|l|c|c|c|c|c|c|}
\hline \multirow{2}{*}{$\begin{array}{c}\text { N } \\
\text { o. }\end{array}$} & \multirow{2}{*}{ Ruang } & \multirow{2}{*}{ Heating } & \multirow{2}{*}{$\begin{array}{c}\text { Dew } \\
\text { Point }\end{array}$} & \multicolumn{2}{|c|}{ Entering } & \multicolumn{2}{|c|}{ Leaving } \\
\cline { 5 - 8 } & & Watt $)$ & & $T d b$ & $T w b$ & $T d b$ & $T w b$ \\
\hline 1 & TPN & 411.1 & 11.7 & 23.2 & 17.2 & 12.8 & 12.2 \\
\hline 2 & Repack & 205.4 & 11.7 & 22.9 & 16.9 & 12.8 & 12.2 \\
\hline 3 & Admixture & 2055.1 & 11.7 & 25.6 & 19.3 & 13.1 & 12.4 \\
\hline 4 & $\begin{array}{l}\text { Cito Toxid } \\
\text { Injection }\end{array}$ & 2055.1 & 11.7 & 25.1 & 18.8 & 13.0 & 12.4 \\
\hline 5 & $\begin{array}{l}\text { Koridor } \\
\text { bersih 1 }\end{array}$ & 411.1 & 11.7 & 23.1 & 17.1 & 12.8 & 12.2 \\
\hline 6 & $\begin{array}{l}\text { Antara } \\
\text { koridor 1 }\end{array}$ & 411.1 & 11.7 & 26.2 & 19.8 & 13.1 & 12.5 \\
\hline 7 & $\begin{array}{l}\text { Koridor } \\
\text { bersih 2 }\end{array}$ & 205.4 & 11.7 & 23.7 & 17.7 & 12.9 & 12.3 \\
\hline 8 & $\begin{array}{l}\text { Antara } \\
\text { koridor 2 }\end{array}$ & 411.1 & 11.7 & 26.2 & 19.8 & 13.1 & 12.5 \\
\hline
\end{tabular}

\section{KESIMPULAN}

Dalam menentukan peralatan, seringkali tidak ditemukan besaran angka yang spesifik sesuai dengan hasil perhitungan. Hal ini disebabkan karena peralatan yang ada dipasaran dibuat berdasarkan rentang kapasitas tertentu, untuk itu dipilih kapasitas peralatan yang berada diatas spesifikasi perancangan supaya kapasitas maksimal dapat dipenuhi oleh peralatan yang dipilih

\section{UCAPAN TERIMA KASIH}

Ucapan terima kasih disampaikan kepada manajemen RSAB Harapan Kita Jakarta yang telah membantu dan memberikan kesempatan untuk mendapatkan data pendukung selama proses perancangan dilakukan, dan kepada Pusat Penelitian dan Pengabdian kepada Masyarakat (P3M) Politeknik Negeri Bandung (Polban) yang telah membantu pembiayaan perancangan.

\section{DAFTAR PUSTAKA}

[1] International Standart ISO 146644-1, "Classification of air cleanliness by particle concentration", second edition, 2015

[2] Peraturan BPOM NO 13 Tahun 2018 tentang CPOB. Badan Pengawas Obat dan Makanan Republik Indonesia, 2018

[3] Gaurav A. Chaudhari, Dr. Suhas H. Sarje,"Clean Room Classification for Pharmaceutical Industry", International Journal of Engineering and Technical Research (IJETR), ISSN: 2321-0869, Volume-3, Issue-4, April 2015

[4] Sanjay Ranade , R.S.Powar, "Design and Development of Cost Effective Clean Rooms For 
Pharmaceutical Units", IOSR Journal of Mechanical and Civil Engineering (IOSR-JMCE), ISSN: 22781684, PP: 07-13

[5] Anamika Singh, Sapna Malviya, Anil Kharia,"Demand of pharmaceutical facility functionality: Validation and qualification of HVAC system", Asian Journal of Pharmaceutics - April-June 2014

[6] Rizky Indriani, C Rangkuti, "Efisiensi energi ruang bersih gedung Batalaktan pabrik farmasi", Prosiding seminar nasional tahunan teknik mesin XV (SNTTM XV) Oktober 2016

[7] Rudi Saputra, Abdunnaser,"Perancangan Instalasi Tata Udara Ruang Bersih Area Penimbangan pada Industri Farmasi Kelas E", Jurnal Bina Teknika, Vol. 14, No. 1, hal. 37-46, 2018

[8] Novi Andriani, Baiti Hidayati,"Perancangan Sistem Tata Udara Gedung Aula SMK Negeri 1 Sekayu", Jurnal Teknik Mesin, Vol. 1, No. 2, hal. 77-84, 2018

[9] Annisa Pramudhita, Rudi Hermawan,"Perancangan Sistem Tata Udara pada Ruang NICU di Lantai 3 Rumah Sakit "X", Jurnal Teknologi Terapan (JTT), Vol.6, No. 2, hal. 125-135, 2020
[10] Shinta Aprilia Safitri, Sarwono, Ridho Hartono,"Desain dan Analisis Sitem Pengkondisian Udara Berbasis Computational Fluid Dynamics (CFD) pada Kereta Ukur Sulawesi di PT INKA (Persero)", Jurnal Teknik ITS, Vol. 7, No. 1, hal. B95-B100, 2018

[11] Susilawati, Andriyanto, Diah Rohayani, Putri Rachmawati,"Kajian Tata Udara Ruang Bersih Kelas B pada Pembuatan Obat Diabetes", Jurnal Quantum Teknika, Vol.2, No. 1, hal. 27-31, 2020

[12] Tenti Tresna Yanti, Rudi Hermawan, "Perancangan system Tata Udara Ruang Bersih Kelas B untuk Ruang Produk Obat di PT. X', Vol. 15 No. 1, hal. 12-20, 2020

[13) ASHRAE, "Handbook Fundamentals", 2017 